\title{
Ichthyofauna of headwater streams from the rio Ribeira de Iguape basin, at the boundaries of the Ponta Grossa Arch, Paraná, Brazil
}

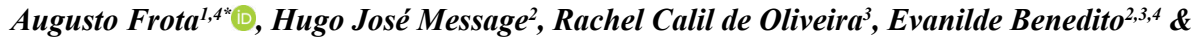 \\ Weferson Júnio da Graça ${ }^{1,2,3,4}$ \\ ${ }^{1}$ Universidade Estadual de Maringá, Coleção Ictiológica do Núcleo de Pesquisas em Limnologia, Ictiologia e \\ Aquicultura, Av. Colombo, 5790. CEP 87020-900. Maringá, PR, Brasil. \\ ${ }^{2}$ Universidade Estadual de Maringá, Centro de Ciências Biológicas, Departamento de Biologia e Núcleo de \\ Pesquisas em Limnologia, Ictiologia e Aquicultura, Av. Colombo, 5790. CEP 87020-900. Maringá, PR, Brasil. \\ ${ }^{3}$ Universidade Estadual de Maringá, Programa de Pós-Graduação em Biologia Comparada, Av. Colombo, \\ 5790. CEP 87020-900. Maringá, PR, Brasil. \\ ${ }^{4}$ Universidade Estadual de Maringá, Programa de Pós-Graduação em Ecologia de Ambientes Aquáticos \\ Continentais, Av. Colombo, 5790. CEP 87020-900. Maringá, PR, Brasil. \\ *Corresponding author: Augusto Frota, e-mail: frota.augusto@gmail.com
}

FROTA, A., MESSAGE, H.J., OLIVEIRA, R.C., BENEDITO, E., GRAÇA, W.J. Ichthyofauna of headwater streams from the rio Ribeira de Iguape basin, at the boundaries of the Ponta Grossa Arch, Paraná, Brazil. Biota Neotropica. 19(1): e20180666, http://dx.doi.org/10.1590/1676-0611-BN-2018-0666.

\begin{abstract}
The rio Ribeira de Iguape basin (Paraná State) is highly relevant for the preservation of remnants of the Atlantic Forest. Its high levels of diversity and fish endemism explain the river dynamics promoted by the Ponta Grossa Arch, a geological structure that promotes headwater capture and isolation between the upper rio Paraná drainage, the rio Iguaçu and the rio Ribeira de Iguape. Here, our objective was to provide an unprecedented inventory for headwater streams of the rio Ribeira de Iguape basin at the boundaries of the Ponta Grossa Arch. We found 29 species of fish representing four orders and nine families. Siluriformes was the richest order followed by Characiformes. Nine species presented high abundance of sampled individuals, contributing with $87.8 \%$ of the collections. Four species appeared in less than $25 \%$ of the sampled sites (occasional), and six species appeared in more than $50 \%$ (constant). We identified three nondescribed species and one non-native (Coptodon rendalli). Two species had their geographical distribution extended and the presence of Astyanax bifasciatus, endemic to the Iguaçu river basin, ratifies recent events of headwater capture between coastal drainages and those that flow into the continent. Studies of biogeographic divisors are necessary to explain the origin and dispersion processes of species in order to direct studies on diversity and preventive management actions. Coptodon rendalli (Tilapia) is an alarming record on the introduction of species in the region.
\end{abstract}

Keywords: Altitudinal gradient, biogeography, coastal drainages, ichthyology, invasion.

\section{Ictiofauna de riachos de cabeceira da bacia do rio Ribeira de Iguape, nos limites do Arco de Ponta Grossa, Paraná, Brasil}

Resumo: A bacia do rio Ribeira de Iguape (Estado do Paraná) é altamente relevante para a preservação de remanescentes da Mata Atlântica. Os seus altos níveis de diversidade e de endemismo de peixes explicam a dinâmica fluvial promovida pelo Arco de Ponta Grossa, estrutura geológica que promove eventos de captura de cabeceira e de isolamento entre as drenagens do alto rio Paraná, do rio Iguaçu e do rio Ribeira de Iguape. Aqui, nosso objetivo foi fornecer um inventário inédito para riachos de cabeceira da bacia do rio Ribeira de Iguape nos limites do Arco de Ponta Grossa. Encontramos 29 espécies de peixes representando quatro ordens e nove famílias. Siluriformes foi a ordem mais rica seguida por Characiformes. Nove espécies apresentaram alta abundância de indivíduos amostrados, contribuindo com $87,8 \%$ das coletas. Quatro espécies apareceram em menos de $25 \%$ dos locais amostrados (ocasionais), e seis espécies apareceram em mais de $50 \%$ (constantes). Identificamos três espécies não descritas e uma (Coptodon rendalli) não nativa. Duas espécies tiveram sua distribuição geográfica ampliada e, a presença de Astyanax bifasciatus, endêmica para a bacia do rio Iguaçu, ratifica eventos recentes de captura de cabeceira entre drenagens costeiras e aquelas que fluem para dentro do continente. Estudos de divisores biogeográficos são necessários para explicar os processos de origem e dispersão de espécies a fim de direcionar estudos sobre diversidade e ações de manejo preventivas. Coptodon rendalli (Tilápia) é um registro alarmante sobre a introdução de espécies na região.

Palavras-chave: Biogeografia, drenagens costeiras, ictiologia, invasão, gradiente altitudinal. 


\section{Introduction}

The most direct means of accessing the biodiversity of a biome or locality is to carry out an inventory of species. The elaboration of any taxonomic list is not trivial, because much effort and time are spent in the specific techniques of sampling for a particular group of organisms as well as gaining the knowledge required about systematics, taxonomy, ecology, and natural history (Silveira et al. 2010). Recognizing the species of fish is essential to design effective conservation and management strategies of aquatic ecosystems (Oliveira et al. 2014; Agostinho et al. 2016; Melo et al. 2016; Ferreira et al. 2017). Therefore, ichthyofaunistic inventories are crucial to robust analyzes of biodiversity involving ecological and biogeographic aspects.

South America is home to many freshwater fishes, with approximately 20 orders, 69 families, 739 genera and 5,160 valid species (Reis et al. 2016). However, knowledge of the actual quantity of species and their geographical distribution is far from complete (Ota et al. 2015). Specifically to the Paraná State, where are numerous river networks, recent inventories of fish (Baumgartner et al. 2012; Pagotto et al. 2012; Frota et al. 2016a; Cavalli et al. 2018) have been improving the knowledge about the state's large sub-basins, yet economically biased by hydroelectric projects financing. Headwater regions of the rivers, with lower profitability of the electric sector, remain without substantial samplings, even though they have a high rate of endemism and are ecologically threated by human occupation (Baumgartner et al. 2012).

Recent studies have provided important records of fish species in headwater streams of the Paraná State, but all of them are limited to the systems of the upper rio Paraná (e.g., Delariva \& Silva 2013; Hoffmann et al. 2015; Cetra et al. 2016; Frota et al. 2016a; Cavalli et al. 2018; Claro-García et al. 2018) and the rio Iguaçu (e.g., Frota et al. 2016b; Larentis et al. 2016; Delariva et al. 2018), which converges to the rio de la Plata system. Many headwater streams located in Atlantic Coastal basins of the Paraná State are unlisted and little is known about which species reside there.

Among the coastal drainages of the Paraná State, the rio Ribeira de Iguape basin is an ecologically relevant region for preserving remaining areas of the Atlantic Forest with high endemism of fish (Oyakawa et al. 2006; Menezes et al. 2007; Oyakawa \& Menezes 2011). The headwaters of the rio Ribeira de Iguape basin stand out the Ponta Grossa Arch. In this important geological structure, recent tectonic activities (see Franco-Magalhães et al. 2010) have resulted in an accelerated fluvial dynamism between drainages of the upper rio Paraná, rio Iguaçu, and rio Ribeira de Iguape. This fact has been proven by the sharing of species by headwater capture events, and or serving as an efficient biogeographic barrier (Ribeiro 2006; Frota et al. 2016a; Morais-Silva et al. 2018). Considering this backdrop, our objective was to provide an inventory for headwater streams' fish of the rio Ribeira de Iguape basin at the boundaries of the Ponta Grossa Arch.

\section{Material and Methods}

\section{Study area}

The rio Ribeira de Iguape basin is in the São Paulo and Paraná states, draining $25,000 \mathrm{~km}^{2}$ and including 25 municipalities in São Paulo and 15 in Paraná. One-third of this area is in Paraná State, which is formed by the confluence of the rios Ribeirinha and Açungui, $85 \mathrm{~km}$ to the north of the capital, Curitiba. Toward to its mouth in the Atlantic Ocean, in the municipality of Iguape (SP), the rio Ribeira de Iguape travels $470 \mathrm{~km}$ through a fairly rugged relief with strong altitudinal gradients, extending from the coastal plain, close to sea level, to the peaks of the mountain, range with more than $1,000 \mathrm{~m}$ of altitude. The rio Ribeira de Iguape basin includes one of the largest remaining areas of Brazil's Atlantic Forest, which despite its critical nature still holds significant biodiversity and endemism (Oyakawa et al. 2006).

The streams of the Atlantic Forest are characterized by beds formed by rocks, presenting clear waters, strong currents, relatively low temperatures, and high concentration of dissolved oxygen (Oyakawa et al. 2006). Streams can be divided into three main types according to their topographical location: 1) mountain streams or headwater streams, 2) lowland streams, and 3) coastal streams. Headwater streams, like those studied here, are characterized by great slope of the relief with thicker bottom substrate and relatively straight channel (Oyakawa et al. 2006).

The basin of the rio Ribeira de Iguape in the Paraná State is bordered to the north by the rio Itararé basin, the rio Tibagi basin to the west (both belong to the upper rio Paraná system), and to the south by the rio Iguaçu basin (Figure 1A). The headwaters of the rio Ribeira de Iguape basin in the Paraná State are located on the boundaries of the Ponta Grossa Arch. This arch involves a large deformational structure with NW-SE trend axis. Its elevation (Figure 1A) varies between more than $1,500 \mathrm{~m}$ in the center and SE, and $600 \mathrm{~m}$ in NW (Franco-Magalhaes et al. 2010).

\section{Data collection}

The specimens were collected under a permanent license to collect zoological material, number 14028-1, granted by the Brazilian Institute of Environment and Renewable Natural Resources (IBAMA, in Portuguese). All the 32 streams were sampled (Table 1; Figure 1B) on six collection trips: October 2014, October 2015, July 2016, October 2016, January 2017, and April 2017. A 100-m stretch was defined at each site, which were georeferenced (Table 1) and sampled by electrofishing. This technique employs two electrified dip nets, producing an electric discharge between 200 and $400 \mathrm{~V}$ and current of $2 \mathrm{~A}$, that stun the fish temporarily (Lobón-Cervia 1991). The specimens were anesthetized in benzocaine hydrochloride and fixed in $10 \%$ formalin in the field. After a few days, the fishes were transferred to $70 \%$ ethanol in the laboratory and deposited in the Coleção Ictiológica do Núcleo de Pesquisas em Limnologia, Ictiologia e Aquicultura (NUP). 

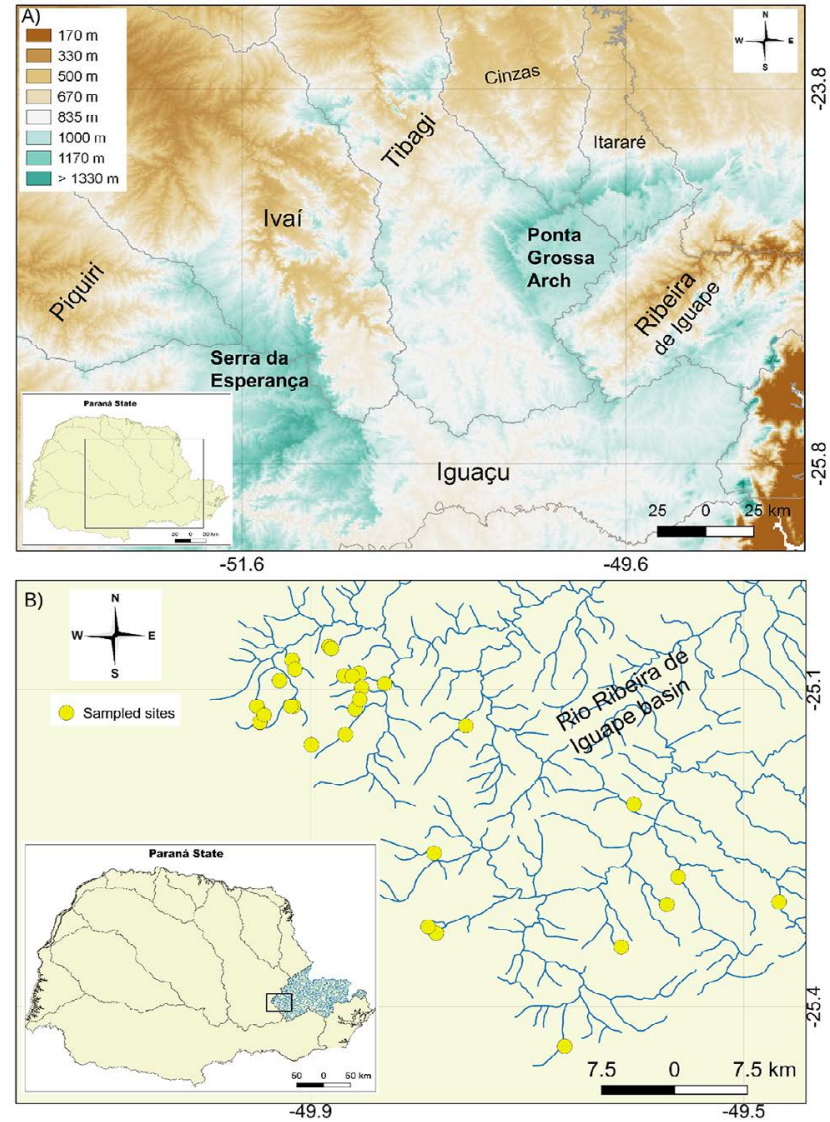

Figure 1. Map of the study area showing: (A) hypsometric map of Paraná State with highlight to the Ponta Grossa Arch, (B) the location of the rio Ribeira de Iguape basin within of the Paraná State, and sampled sites in headwater streams.
Fish species were classified based on Eschmeyer \& Fong (2018) and species determinations were accomplished by comparison of the specimens with original descriptions or with type specimens of species reported from rio Ribeira de Iguape basin by Oyakawa et al. (2006), Menezes et al. (2007) and Oyakawa \& Menezes (2011). Whenever possible, the determinations of the species were checked by specialists of each taxonomic group. The species were categorized by their frequency of occurrence (hereafter, constancy), which was calculated for all sampled streams according to Dajoz (1983). Species with a constancy up to $25 \%$ were classified as occasional, between 25 and $50 \%$ as accessory, and higher than $50 \%$ as constant. In addition, the species were categorized by origin into autochthonous and allochthonous, respectively, to distinguish native and introduced species to the rio Ribeira de Iguape basin, following Oyakawa et al. (2006), Menezes et al. (2007), and Oyakawa \& Menezes (2011).

\section{Results}

There were collected a total of 5,617 individuals distributed in four orders, nine families, and 29 species (Tables 1 and 2; Figures 2 and 3 ). Siluriformes (Figure 4) was the most representative order in number of species and families (16 species and four families), followed by Characiformes (nine species and three families). Among the families, Loricariidae and Characidae, both with seven species, presented higher richness contributing together with approximately $48.3 \%$ of all collected species, followed by Heptapteridae (five species) with approximately $17.3 \%$ of all collected species (Figure 5).

Table 1. Information on the headwater streams sampled in the rio Ribeira de Iguape basin, Paraná State, Brazil. Numbers in parentheses after each species name indicates abundance.

\begin{tabular}{|c|c|c|c|c|c|}
\hline $\begin{array}{c}\text { Sample } \\
\text { point }\end{array}$ & Remarks & $\begin{array}{l}\text { Altitude } \\
\text { (meters) }\end{array}$ & Coordinates & Municipality & Species caught \\
\hline 1 & $\begin{array}{l}\text { Rio da Mata, affluent } \\
\text { of rio Açungui, rio } \\
\text { Ribeira de Iguape } \\
\text { basin }\end{array}$ & $\sim 745$ & $\begin{array}{c}25^{\circ} 19^{\prime} 49.5^{\prime \prime S} \\
49^{\circ} 47^{\prime} 2.4^{\prime \prime} \mathrm{W}\end{array}$ & Ponta Grossa & $\begin{array}{l}\text { Astyanax laticeps (2), Astyanax bifasciatus (39), } \\
\text { Bryconamericus microcephalus (15), Cambeva davisi (13), } \\
\text { Characidium pterostictum (39), Chasmocranus lopezae } \\
\text { (11) Harttia kronei (22), Isbrueckerichthys duseni (35), } \\
\text { Pimelodella transitoria (17) and Rineloricaria kronei (2) }\end{array}$ \\
\hline 4 & $\begin{array}{l}\text { Rio Caçador, affluent } \\
\text { of rio Conceição, rio } \\
\text { Ribeira de Iguape basin }\end{array}$ & $\sim 727$ & $\begin{array}{c}25^{\circ} 8^{\prime} 4.2^{\prime \prime} \mathrm{S} \\
49^{\circ} 45^{\prime} 23.9^{\prime \prime} \mathrm{W}\end{array}$ & Ponta Grossa & $\begin{array}{c}\text { Cambeva davisi (2), Characidium pterostictum (15), } \\
\text { Harttia kronei (44), Isbrueckerichthys duseni (47), } \\
\text { Kronichthys lacerta (2), Neoplecostomus ribeirensis (2) } \\
\text { and Phalloceros harpagos (1) }\end{array}$ \\
\hline
\end{tabular}


Frota, A. et al

5

Rio Ribeirão, affluent of rio Açungui, rio Ribeira de Iguape basin

6

Rio do Cerne, affluent of rio

Açungui, rio Ribeira de Iguape basin

7

Rio Açungui, affluent of rio Ribeira de Iguape, rio Ribeira de Iguape basin

Rio Retiro, affluent of rio Açungui, rio Ribeira de Iguape basin

Riacho Boa Vista, affluent of rio

Açungui, rio Ribeira de Iguape basin

Rio Conceição, affluent of rio Ribeira de Iguape, rio Ribeira de Iguape basin

Unnamed river, affluent of Arroio Passo do Nenê, rio Ribeira de Iguape basin Unnamed river, affluent of Arroio Itaguá, rio Ribeira de Iguape basin affluent of rio de Iguape basin affluent of Ribeirão de Iguape basin $25^{\circ} 16^{\prime} 38.9^{\prime \prime} \mathrm{S}$, 49³3'38.6"W

2526'14.6"S, 4939'55.3"W

$\sim 904$

$25^{\circ} 20^{\prime} 36.6^{\prime \prime} \mathrm{S}$, $49^{\circ} 36^{\prime} 47.5^{\prime \prime} \mathrm{W}$

$25^{\circ} 18^{\prime} 12.5^{\prime \prime} \mathrm{S}$, $49^{\circ} 34^{\prime} 15.9^{\prime \prime} \mathrm{W}$

$25^{\circ} 18^{\prime} 3.5^{\prime \prime} \mathrm{S}$, $49^{\circ} 28^{\prime} 3.2^{\prime \prime} \mathrm{W}$

$\sim 773$ 49.2

$5^{\circ} 17^{\prime} 57.3^{\prime \prime S}$, $49^{\circ} 24^{\prime} 39.2^{\prime \prime} \mathrm{W}$

$25^{\circ} 15^{\prime} 44.5^{\prime \prime} \mathrm{S}$ $49^{\circ} 23^{\prime} 57.2^{\prime \prime} \mathrm{W}$ Grande, rio Ribeira

253'34.14"S, $49^{\circ} 52^{\prime} 58.83^{\prime \prime} \mathrm{W}$

$25^{\circ} 7^{\prime} 7.19^{\prime \prime} \mathrm{S}$, 49 51'31.59"W

$25^{\circ} 5^{\prime} 55.23^{\prime \prime S}$, $49^{\circ} 51^{\prime} 10.39^{\prime \prime} \mathrm{W}$

$25^{\circ} 4^{\prime} 20.07^{\prime \prime} \mathrm{S}$, $49^{\circ} 55^{\prime} 1.74 " \mathrm{~W}$ 49 $54^{\circ} 52.29^{\prime \prime} \mathrm{W}$
Campo Largo

Cambeva davisi (2), Chasmocranus lopezae (6), Corydoras ehrhardti (5), Deuterodon iguape (41), Geophagus iporanguensis (1), Harttia kronei (26), Hypostomus interruptus (1), Isbrueckerichthys duseni (7), Kronichthys lacerta (4), Neoplecostomus ribeirensis (1), Rhamdia quelen

(1) and Rhamdioglanis transfasciatus (10)

Campo Largo

Astyanax laticeps (34), Cambeva davisi (2), Corydoras ehrhardti (10), Geophagus iporanguensis (13), Harttia kronei (14), Hypostomus interruptus (1), Isbrueckerichthys duseni (20), Kronichthys lacerta (6), Phalloceros harpagos (12), Rhamdia quelen (3) and Rineloricaria kronei (31)

Campo Largo

Astyanax bifasciatus (15), Astyanax laticeps (44), Cambeva davisi (9), Chasmocranus lopezae (2), Harttia kronei (5), Isbrueckerichthys duseni (3), Pimelodella transitoria (18), Rhamdia quelen (2), Kronichthys lacerta (1), Phalloceros harpagos (3) and Rineloricaria kronei (1)

Campo Largo Astyanax laticeps (13), Isbrueckerichthys duseni (6), Phalloceros harpagos (1) and Rhamdia quelen (3)

Campo Largo Cambeva davisi (21), Phalloceros harpagos (17) and Rhamdia quelen (1)

Campo Magro

Astyanax laticeps (44), Chasmocranus lopezae (3), Corydoras ehrhardti (16), Geophagus iporanguensis (4), Harttia kronei (10), Hoplias aff. malabaricus (1), Isbrueckerichthys duseni (38), Kronichthys lacerta (2), Phalloceros harpagos (7), Parotocinclus maculicauda (3), Rhamdia quelen (3) and Rineloricaria kronei (5) Astyanax laticeps (17), Cambeva davisi (2), Harttia kronei (71), Isbrueckerichthys duseni (50), Neoplecostomus ribeirensis (10), Phalloceros harpagos (1) and Rhamdia quelen (1)

Astyanax laticeps (9), Astyanax bifasciatus (1), Cambeva davisi (1), Corydoras ehrhardti (1), Geophagus iporanguensis (4), Isbrueckerichthys duseni (52),

Neoplecostomus ribeirensis (5) and Rhamdia quelen (9)

Ponta Grossa

Astyanax lacustris (42), Astyanax laticeps (1), Astyanax sp. 1 (5), Cambeva davisi (48), Geophagus iporanguensis (24), Hypostomus interruptus (1), Isbrueckerichthys duseni (6) and Phalloceros harpagos (228)

Ponta Grossa

Ponta Grossa

Astyanax sp. 1 (2) and Isbrueckerichthys duseni (13)

Astyanax sp. 1 (1), Geophagus iporanguensis (2), Hoplias aff. malabaricus (1), Hypostomus interruptus (4), Isbrueckerichthys duseni (51), Phalloceros harpagos (15) and Rhamdia quelen (4)

Ponta Grossa

Cambeva davisi (22), Chasmocranus lopezae (1), Coptodon rendalli (10), Geophagus iporanguensis (95), Hoplias aff. malabaricus (7), Hypostomus interruptus (66), Isbrueckerichthys duseni (4), Kronichthys lacerta (3), Phalloceros harpagos $(1,637)$, Pimelodella transitoria (2) and Rhamdia quelen (4)

Cambeva davisi (18), Geophagus iporanguensis (2) and Phalloceros harpagos (318)

Itaguá, rio Ribeira de Iguape basin 


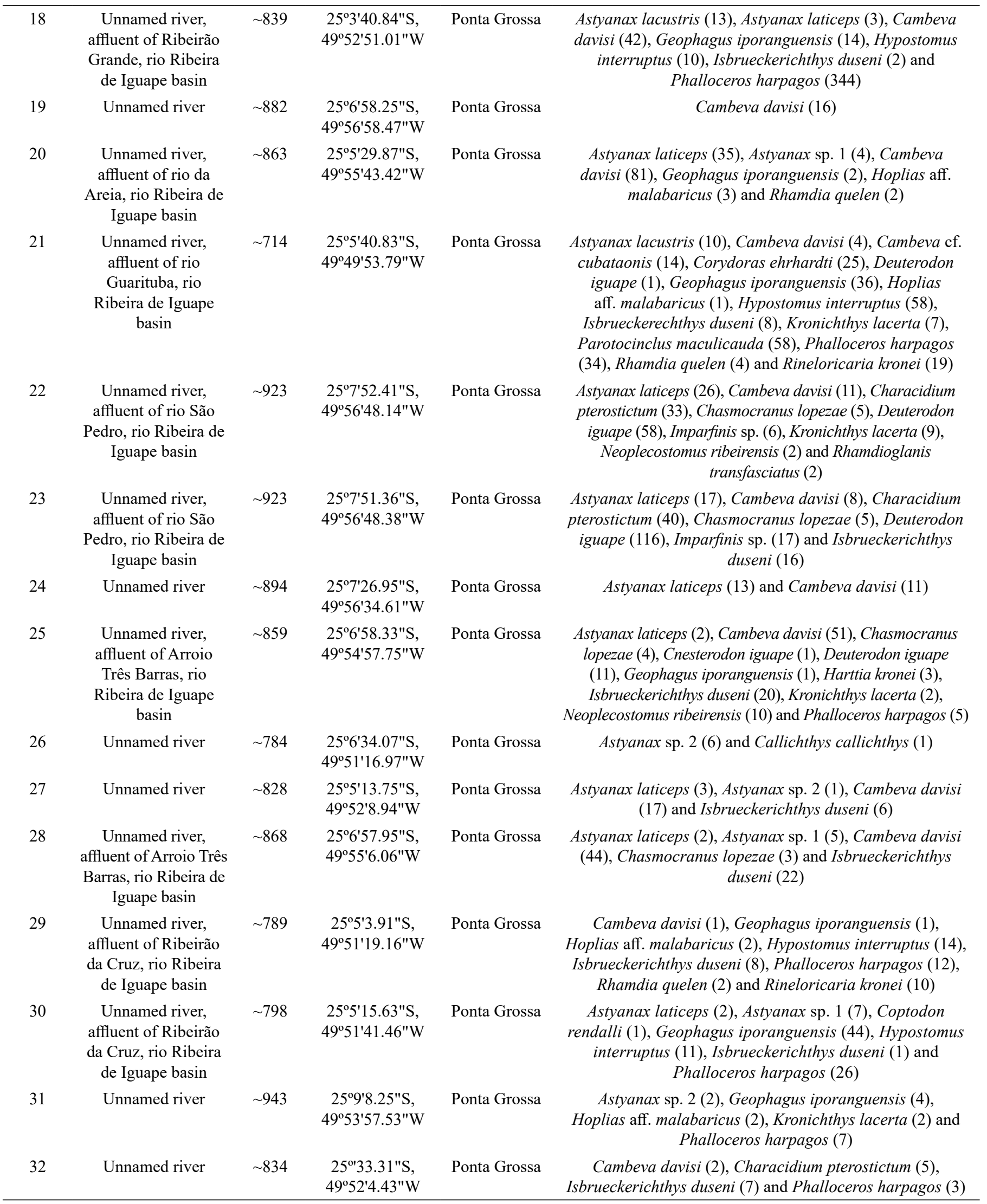


Frota, A. et al.

Table 2. Fish species collected in headwater streams from the rio Ribeira de Iguape basin, at the boundaries of the Ponta Grossa Arch, Paraná State, Brazil.

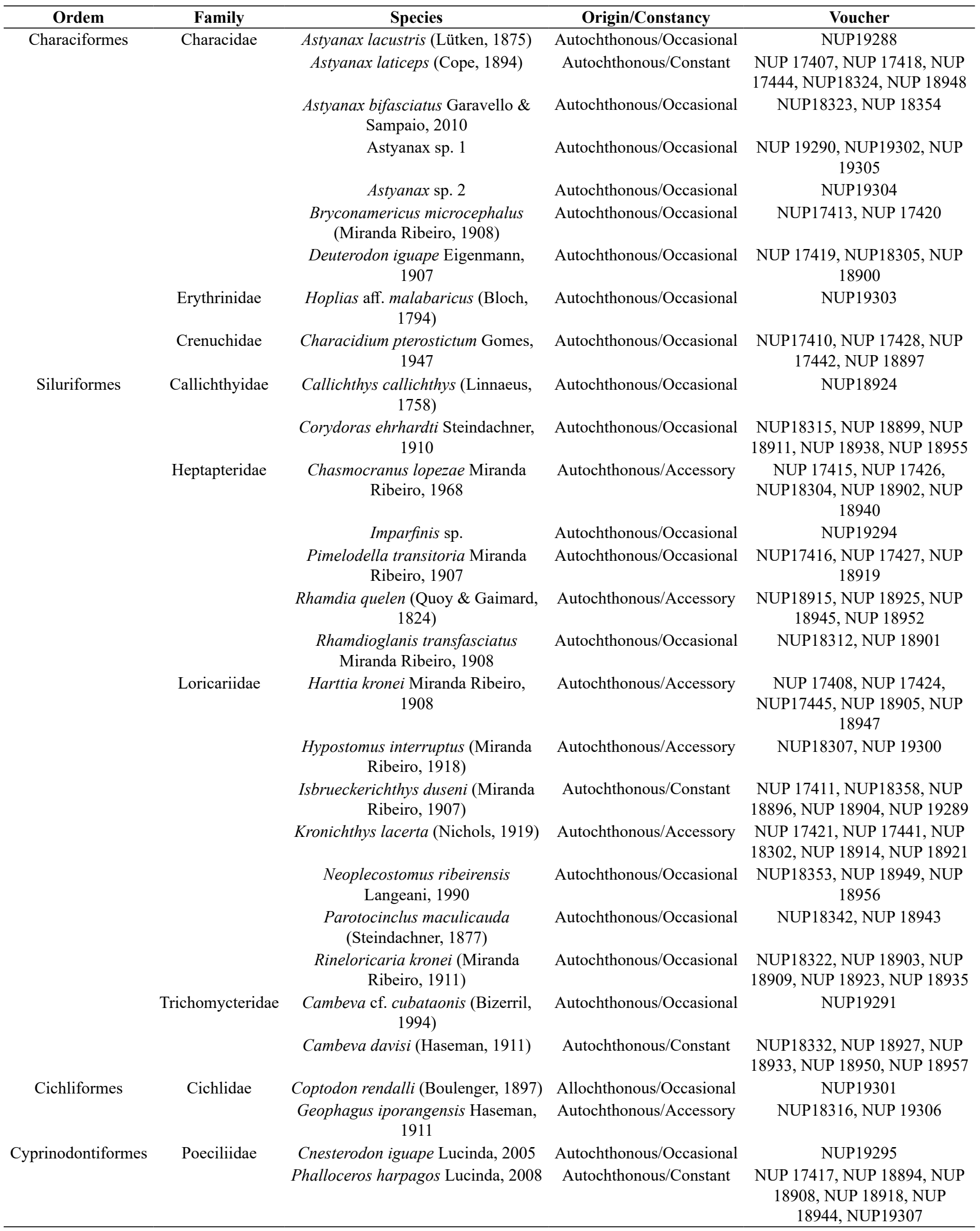




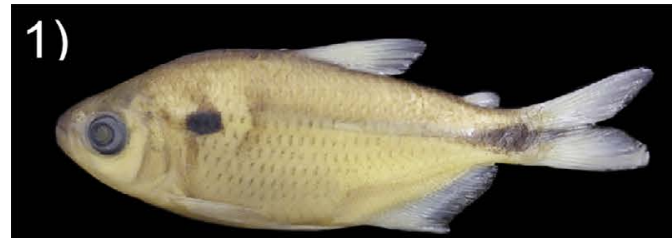

3)

5)
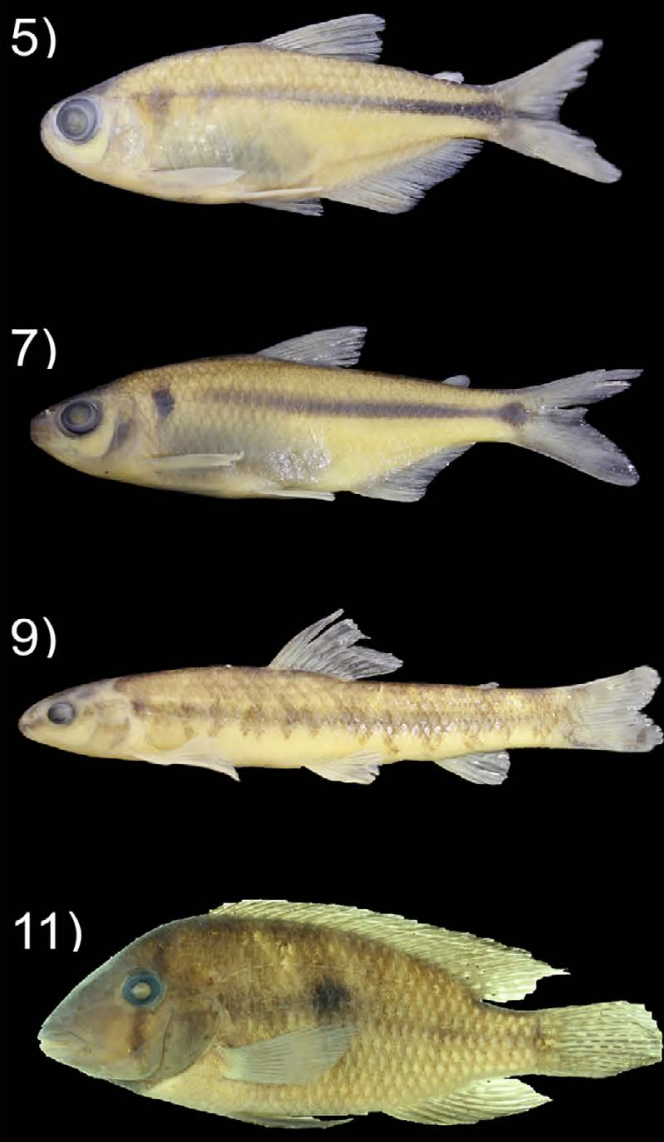

2)

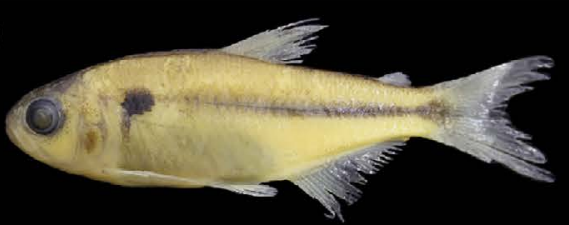

4)

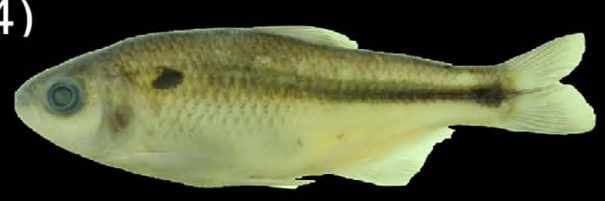

6)
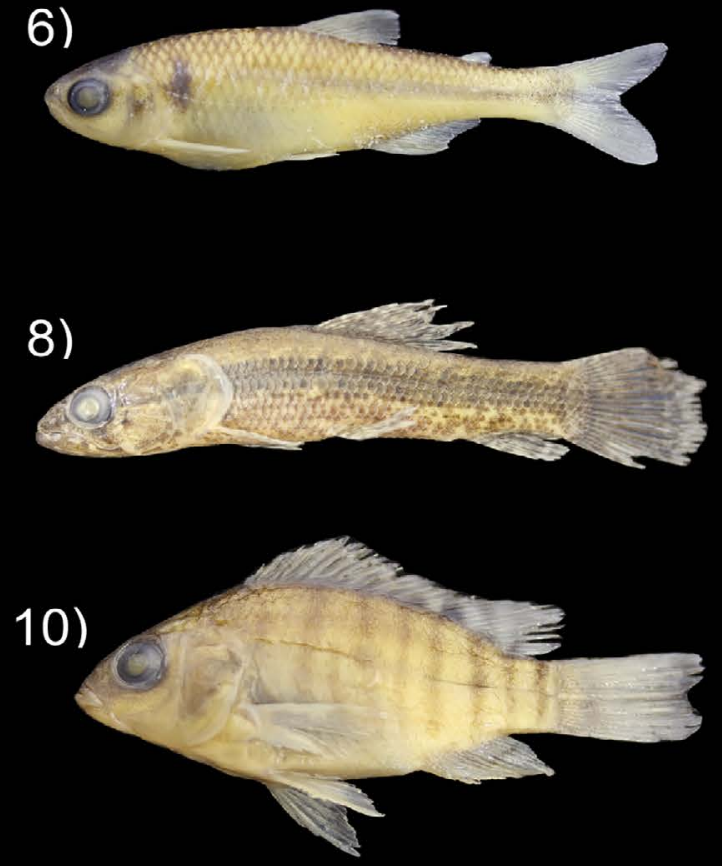

12)

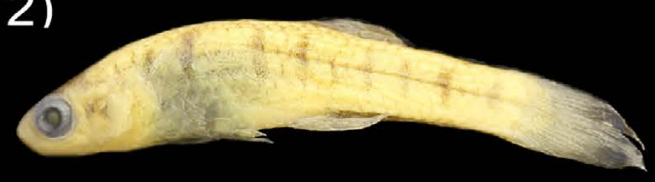

\section{3)}

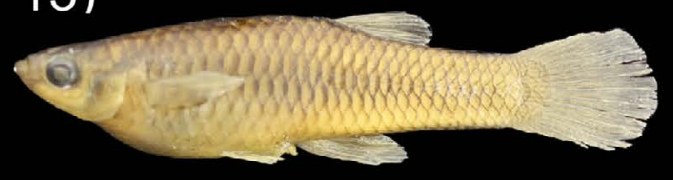

Figure 2. Representative individuals of the Characiformes, Cichliformes and Cyprinodontiformes registred to the headwater streams from the rio Ribeira de Iguape basin, at the Ponta Grossa Arch boundaries, Paraná State, Brazil. Their catalogue numbers in the Coleção Ictiológica do Nupélia (NUP) and standard lengths are presented after the names of species. 1) Astyanax lacustris, NUP 19288, $61.1 \mathrm{~mm}$; 2) Astyanax laticeps, NUP 18324, 40.4 mm; 3 ) Astyanax bifasciatus, NUP 18354, 75.0 mm; 4) Astyanax sp. 1, NUP 19302, 72.2 mm; 5) Astyanax sp. 2, NUP 19304, 48.2 mm; 6) Bryconamericus microcephalus, NUP 17413, 47.8 mm; 7) Deuterodon iguape, NUP 18305, $71.4 \mathrm{~mm}$; 8) Hoplias aff. malabaricus, NUP 19303, $56.0 \mathrm{~mm}$; 9) Characidium pterostictum, NUP 17410, 53.7 mm; 10) Coptodon rendalli, NUP 19301, 34.8 mm; 11) Geophagus iporangensis, NUP 18316, 120.4 mm; 12) Cnesterodon iguape, NUP 19295, 24.5 mm; 13) Phalloceros harpagos, NUP 17417, $31.3 \mathrm{~mm}$. 


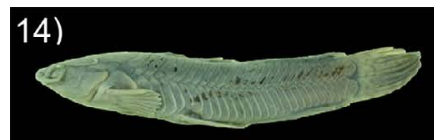

15)
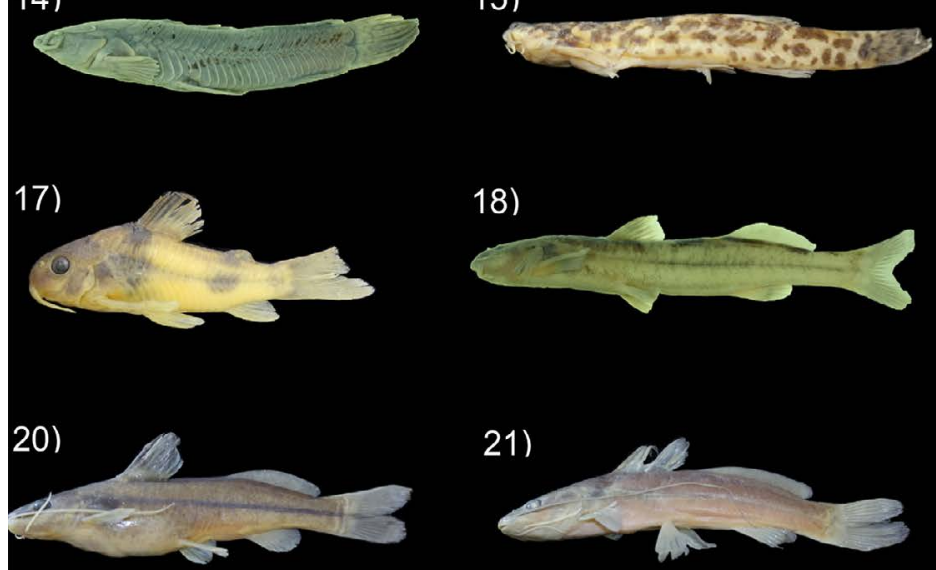

18)
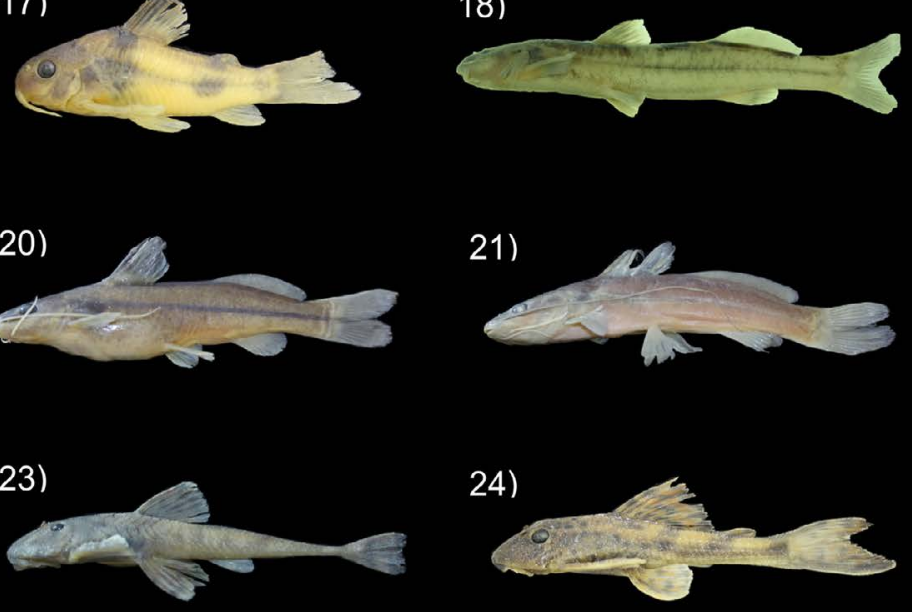
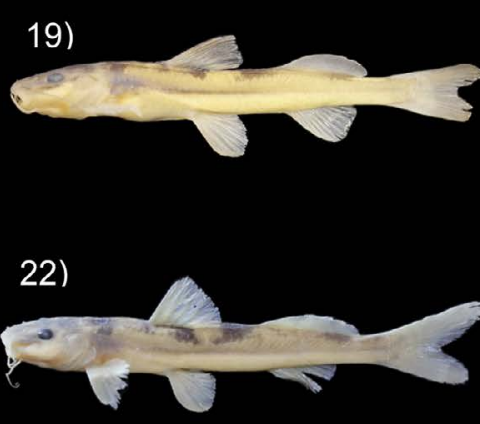

16)
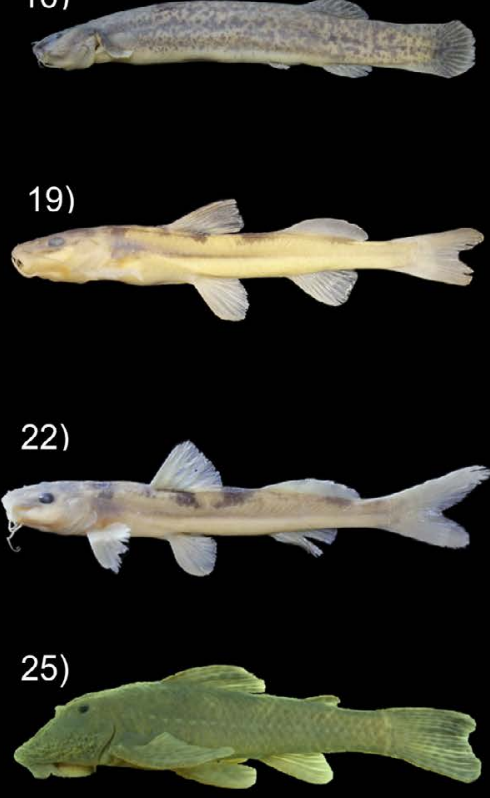

26)

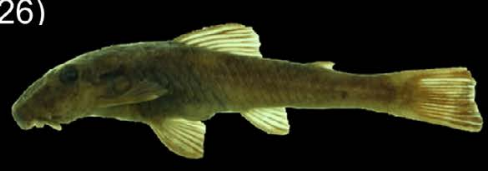

28)

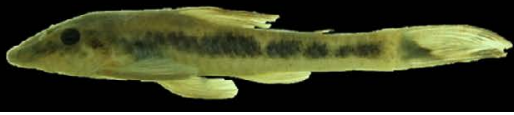

\section{7)}

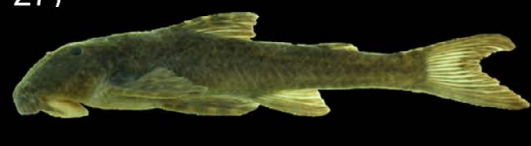

Figure 3. Representative individuals of the Siluriformes registred to the headwater streams from the rio Ribeira de Iguape basin, at the Ponta Grossa Arch boundaries, Paraná State, Brazil. Their catalogue numbers in the Coleção Ictiológica do Nupélia (NUP) and standard lengths are presented after the names of species. 14) Callichthys callichthys, NUP 18924, $75.9 \mathrm{~mm}$; 15) Cambeva cf. cubataonis, NUP 19291, $41.4 \mathrm{~mm}$; 16) Cambeva davisi, NUP 18332, 94.9 mm; 17) Corydoras ehrhardti, NUP 18315, $38.5 \mathrm{~mm}$; 18) Chasmocranus lopezae, NUP 18304, $103.6 \mathrm{~mm}$; 19) Imparfinis sp., NUP19294, 63.5 mm; 20) Pimelodella transitoria, NUP 17416, $100.9 \mathrm{~mm}$; 21) Rhamdia quelen, NUP 18915, $90.3 \mathrm{~mm}$; 22) Rhamdioglanis transfasciatus, NUP 18312, $118.3 \mathrm{~mm}$; 23) Harttia kronei, NUP $17445,68.8$ $\mathrm{mm}$; 24) Hypostomus interruptus, NUP 18307, $57.8 \mathrm{~mm}$; 25) Isbrueckerichthys duseni, NUP 18358, $111.1 \mathrm{~mm}$; 26) Kronichthys lacerta, NUP 18302, $51.5 \mathrm{~mm}$; 27) Neoplecostomus ribeirensis, NUP 18353, 68.2 mm; 28) Parotocinclus maculicauda, NUP 18342, 42.0 mm; 29) Rineloricaria kronei, NUP $18322,109.6$ mm.

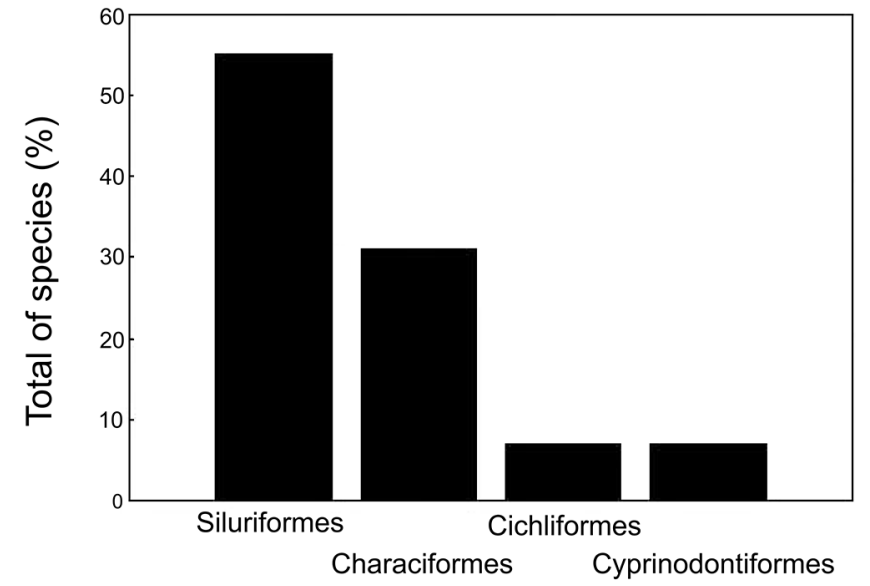

Figure 4. Percentages of the total number of collected species in each order in the headwater streams from rio Ribeira de Iguape basin, Paraná State, Brazil.

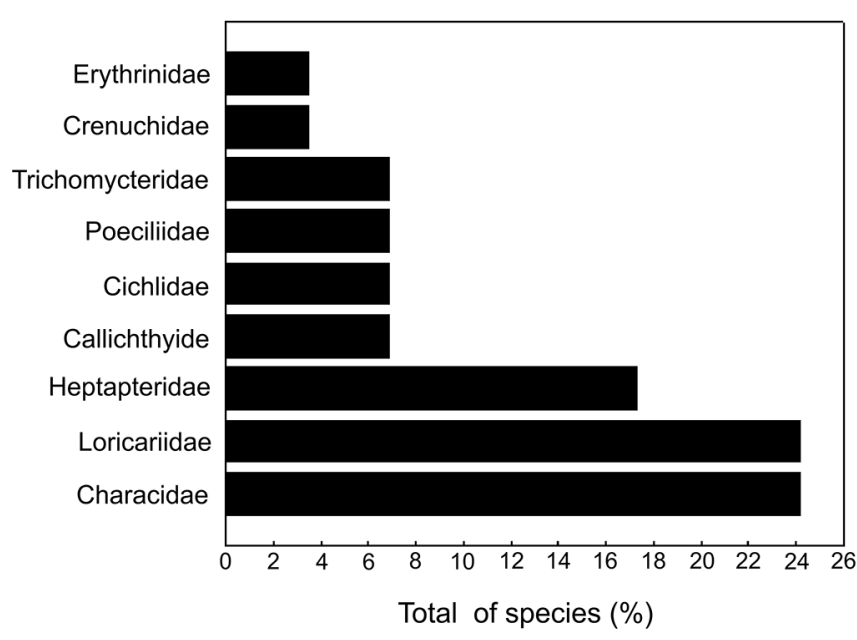

Figure 5. Percentages of the total number of collected species in each family in the headwater streams from rio Ribeira de Iguape basin, Paraná State, Brazil. 
Regarding the abundance of the individuals sampled (Figure 6), Phalloceros harpagos Lucinda, 2008 (2,720 individuals), Isbrueckerichthys duseni (Miranda Ribeiro, 1907) (460 individuals), Cambeva davisi (Haseman, 1911) (445 individuals), Astyanax laticeps (Cope, 1894) (308 individuals), Geophagus iporangensis Haseman, 1911 (248 individuals), Deuterodon iguape Eigenmann, 1907 (231 individuals), Harttia kronei Miranda Ribeiro, 1908 (211 individuals), Hypostomus interruptus (Miranda Ribeiro, 1918) (166 individuals), and Characidium pterostictum Gomes, 1947 (147 individuals) were the most abundant species, contributing with approximately $87.8 \%$ of all collected individuals. On the other hand, the other 20 species did not have 100 individuals collected.

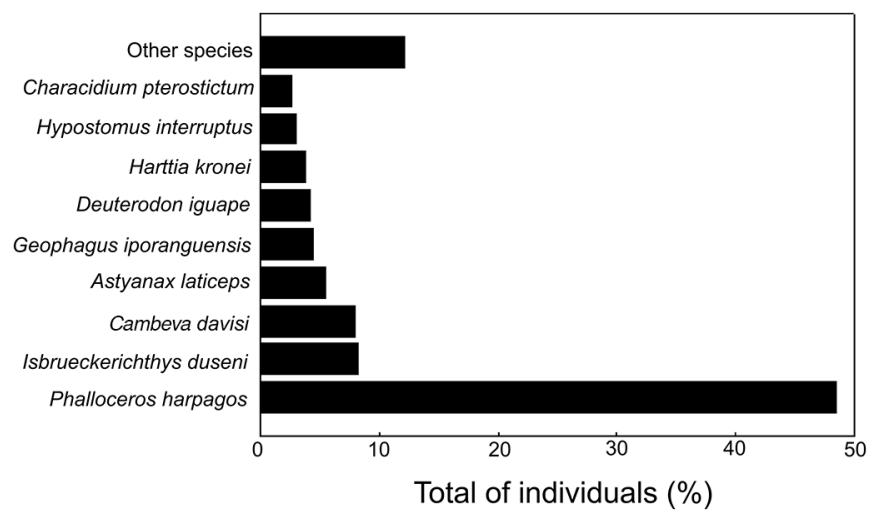

Figure 6. Percentages of number of individuals of each species with more than 100 individuals collected in the headwater streams from the rio Ribeira de Iguape basin, Paraná State, Brazil.

As for constancy (Table 2), most of the species were categorized as occasional (19 species). Four species (Astyanax laticeps, Isbrueckerichthys duseni, Phalloceros harpagos, and Cambeva davisi) were categorized as constant, and the six (Chasmocranus lopezae Miranda Ribeiro, 1968, Rhamdia quelen (Quoy \& Gaimard, 1824), Harttia kronei, Hypostomus interruptus, Kronichthys lacerta (Nichols, 1919), and Geophagus iporangensis) were categorized as accessory. There were collected three putatively undescribed species: Astyanax sp. 1, Astyanax sp. 2, and Imparfinis sp. Individuals collected of Cnesterodon iguape Lucinda, 2005 and Cambeva cf. cubataonis (Bizerril, 1994) represent an expansion to their geographical distribution beyond the type locality. The new record of Astyanax bifasciatus Garavello \& Sampaio, 2010 to the rio Ribeira de Iguape basin may give more evidence of ichthyofaunistic exchange among basins in the region. Considering the origin of species (Table 2), only Coptodon rendalli (Boulenger, 1897) was classified as allochthonous.

\section{Discussion}

This inventory recorded 29 fish species for the headwaters streams of the rio Ribeira de Iguape basin (nearly $39.7 \%$ of the total recorded in Oyakawa et al. 2006, a key publication for this basin). The highest number of species in Siluriformes and Characiformes follows the pattern of the Neotropical region of fish diversity (Castro 1999, LoweMcConnell 1999, Buckup et al. 2007) and meets the samplings already carried out in the rio Ribeira de Iguape basin (e.g., Oyakawa et al. 2006; Oyakawa \& Menezes 2007; Cetra et al. 2012; Barrella et al. 2014).
Headwaters streams of the Atlantic Forest present high velocity of water flow and a mosaic of large rocks, which favors species with morphology to fixation and support (Oyakawa et al. 2006; Ferreira et al. 2010), as the sucker mouths of Loricariidae, and spines in the fins of Heptapteridae and in the operculum Trichomycteridae. Environments with fast-flowing and rocky riverine habitats (like those ones we sampled here) are local incubators of the diversification and biological specialization, promoting high rates of diversification of lineages and phenotypes, especially for Loricariidae (Roxo et al. 2017). The Atlantic Coastal basins contain low-diversity lineages of loricariids and with early-branching restricted to these drainages (Roxo et al. 2014), reinforcing the importance of the rio Ribeira do Iguape basin to the evolution and conservation of Loricariidae (Roxo et al. 2012). Characidae is widely recognized as the family with the most number of species in the Neotropical region, and the fourth among all the actinopterygian (Mirande 2018). The high diversity of mesohabitats in streams of the Atlantic Forest (backwaters separated by rapids) allow species adapted to live in the water column as the characids (Oyakawa et al. 2006; Ferreira et al. 2010).

Oyakawa et al. (2006) mentioned Phalloceros caudimaculatus (Hensel, 1868), however, in the systematic review of Phalloceros Eigenmann, 1907, Lucinda (2008) described that $P$. harpagos presents a wider geographical distribution, covering the rio Paraná-Paraguay basin and the coastal drainages of the rio Itaboapana (Espirito Santo State) and rio Araranguá (Santa Catarina State), and restriced P. caudimaculatus to southern of South America. The individuals sampled here were $P$. harpagos and had a wide distribution in practically all types of environments of the rio Ribeira de Iguape basin, from those with high contents of dissolved oxygen and with strong flow, to backwaters, with low dissolved oxygen and higher temperatures (Oyakawa et al. 2006). Due to the wide range of environmental conditions that $P$. harpagos supports, the viviparity, and the coexistence of juveniles and adults in the same habitats (Mazzoni et al. 2011), its abundance recorded here reflected a discrepant dominance of this species.

In general, occasional species were more numerous in the streams sampled here. Probably at least part of the explanation is the influence of the altitudinal gradient. Studies about elevational gradients frequently report a decrease in species richness with increasing altitude ( $\mathrm{Fu}$ et al. 2004; Jaramillo-Villa et al. 2010), and an increase of the number of endemic species in headwaters regions (Carvajal-Quintero et al. 2015). Our sampling showed that some constant or accessory species (e.g. Harttia kronei, Hypostomus interruptus, Isbrueckerichthys duseni and Cambeva davisi) also present the highest frequencies of abundance. These species has morphological structures adapted to the fixation in structures underwater an withstand the force of the water flow, like species of Characidium, and members of Heptapteridae, Loricariidae, and Trichomycteridae (Oyakawa et al. 2006). Thereby, these species can colonize environments at higher altitudes.

The putatively undescribed species collected highlighted a gap in the taxonomic knowledge about headwater regions, meeting the biodiversity shortfalls, which are the gaps between existing evolutionary knowledge and the complete knowledge of a particular biological domain at a certain point in time (Hortal et al. 2015). These shortfalls are a direct consequence of the complexity generated by an evolutionary system, in which the rate of production of new entities exceeds the maximum rate at which we can describe them. 
It should be noted that many species are disappearing without being known, cataloged or formally described, what was called by Brown \& Lomolino (1998) as Linnean shortfall. A similar case of biodiversity shortfall refers to the lack of knowledge of the actual geographical distribution of organisms, named Wallacean shortfall (Lomolino 2004). The two species (Cnesterodon iguape and Cambeva cf. cubataonis) that have expanded their geographic distributions beyond their type locality showed this gap, which may be strongly dangerous in relation to the historical patterns of biogeographic data analysis (Meyer et al. 2015). Thus, our samplings support an inherent concern related to the probable biodiversity shortfalls existing in the ichthyofauna of the headwaters streams from the rio Ribeira de Iguape basin.

The presence of Astyanax bifasciatus, an endemic species of the rio Iguaçu system (Garavello \& Sampaio 2010; Baumgartner et al. 2012), corroborates recent events of headwater captures between coastal drainages and those that flow into the interior of the continent. Studies of biogeographic divisors are necessary in attempts to explain the processes of origin and dispersion of species (Barton 1988). Watershed dividers, such as high mountains (Ponta Grossa Arch, for example), are often seen as effective dispersion barriers for fish, and fish distributions are used to assign river basin boundaries (Ingenito \& Buckup 2007). Clearly, the fish composition of the rio Ribeira de Iguape basin is very different from the neighboring basins (see Ingenito et al. 2004; Hoffmann et al. 2015; Cetra et al. 2016; Claro-García et al. 2018). The formation of the Ponta Grossa Arch represents a barrier for fish populations and, in addition, due to their recent tectonic activities (Franco-Magalhaes et al. 2010), some species have been shared between the rio Ribeira de Iguape basin and neighboring basins of the upper rio Paraná and rio Iguaçu systems (Ribeiro 2006, Morais-Silva et al. 2018), constituting a characteristic pattern recognized by Ribeiro (2006) as "Pattern C". This pattern represents recent vicariant events between the upland crystalline shield rivers and the adjacent coastal drainages leading to the sharing of fish species and the formation of truly hybrid zones. Thus, the limits of the Ponta Grossa Arch bring interesting patterns of geographic distribution of the ichthyofauna with great effects in biogeographical and phylogeographic studies (Morais-Silva et al. 2018).

The presence of the allochthonous species Coptodon rendalli (popularly known as "tilapia") is an alarming record! Numerous fish farms are in full swing and breed non-native species that present a high risk of invasion in natural environments such as tilapia. Several authors have affirmed the invading potential of fish farms and the negative effects of new introductions (e.g., Orsi \& Agostinho 1999, Daga et al. 2015, Daga et al. 2016, Lima et al. 2018). Tilapias significantly change native aquatic communities due to predation of eggs and larvae, aggressive competition for space and food (Sanches et al. 2012), and alteration of the substrate for nest building and predation of zooplankton, which inevitably increases the levels of eutrophication causing changes in the limnological parameters and consequently affecting the native species (Figueredo \& Giani 2005; Córdova-Tapia et al. 2015). Thus, Brazil should adopt restriction and control measures for species with high invasion potential, as well as invest in technologies to prevent fish farm leakage in order to control the introduction of tilapia in natural environments (Padial et al. 2017; Alves et al. 2018, Cassemiro et al. 2018; Gubiani et al. 2018).

\section{Conclusions}

Progress in Neotropical ichthyology depends on the biotic inventory of poorly sampled areas for identification of fish diversity (Schaefer 1998). For this inventory, we provide samplings in headwater streams of the rio Ribeira de Iguape basin in a location of high altitudes with interesting biogeographic patterns and inserted in Conservation Units in the Paraná State. Again, Atlantic Forest streams show a high degree of endemism in relation to their fish, therefore, the data obtained here may provide support for future biogeographic, ecological and conservationist studies.

\section{Author Contributions}

Augusto Frota: contributed to data acquisition, analysis and interpretation of data, drafting of the manuscript and wrote the paper.

Hugo José Message: contributed to analysis and interpretation of data, and critical revision for adding substantive intellectual content.

Rachel Calil de Oliveira: contributed to data acquisition and drafting of the manuscript.

Evanilde Benedito: contributed to analysis and interpretation of data, and critical revision for adding substantive intellectual content.

Weferson Júnio da Graça: contributed to data acquisition, analysis and interpretation of data, and critical revision for adding substantive intellectual content.

\section{Conflicts of Interest}

The authors declare that they have no conflict of interest related to the publication of this manuscript.

\section{References}

AGOSTINHO, A.A., GOMES, L.C., SANTOS, N.C.L., ORTEGA, J.C.G. \& PELICICE, F.M. 2016. Fish assemblages in Neotropical reservoirs: colonization patterns, impacts and management. Fish. Res. 173: 26-36.

ALVES, G.H.Z., TÓFOLI, R.M., MESSAGE, H.J., LIMA-JÚNIOR, D.P. \& HOEINGHAUS, D.J. 2018. New decree promotes fish invasion in Amazon and Pantanal. Biodivers. Conserv. 27(9): 2449-2450.

BARRELlA, W., MARTINS, A.G., PETRERE JR., M. \& RAMIRES, M. 2014. Fishes of the southeastern Brazil Atlantic Forest. Environ. Biol. Fish 87(12): 1367-1376.

BARTON, N.H. 1988. Speciation. In Analytical biogeography, an integrated approach to the study of animal and plant distributions (A.A. Myers, \& P.S Giller, eds). Campman and Hall, Londres, p.185-218.

BAUMGARTNER, G., PAVANELLI, C.S., BAUMGARTNER, D., BIFI, A.G., DEBONA, T. \& FRANA, V.A. 2012. Peixes do Baixo Rio Iguaçu. Eduem, Maringá.

BROWN, J.H. \& LOMOLINO, M.V. 1998. Biogeography. Sinauer Press, Sunderland, Massachusetts.

BUCKUP, P.A., MENEZES, N.A. \& GHAZZI, M.S. 2007. Catálogo das espécies de peixes de água doce do Brasil. Museu Nacional (UFRJ), Rio de Janeiro.

CASSEMIRO, F.A.S., BAILLY, D., GRAÇA, W.J. \& AGOSTINHO, A.A. 2018. The invasive potential of tilapias (Osteichthyes, Cichlidae) in the Americas. Hydrobiologia 817(1): 133-154.

CASTRO, R.M.C. 1999. Evolução da ictiofauna de riachos sul americanos: padrões gerais e possíveis processos casuais. In Ecologia de peixes de riachos: estado atual e perspectivas (E.P. Caramaschi, R. Mazzoni \& P.R. Peres-Neto, eds). UFRJ, Rio de Janeiro, p.139-155. 
CÓRDOVA-TAPIA, F., CONTRERAS, M. \& ZAMBRANO, L. 2015. Trophic niche overlap between native and non-native fishes. Hydrobiologia 746(1): 291-301.

CARVAJAL-QUINTERO, J.D., ESCOBAR, F., ALVARADO, F., VILLANAVARRO, F.A., JARAMILLO-VILLA, Ú. \& MALDONADO-OCAMPO. 2015. Variation in freshwater fish assemblages along a regional elevation gradient in the northern Andes, Colombia. Ecol. Evol. 5(13): 2608-2620.

CAVALLI, D., FROTA, A., LIRA, A.D., GUBIANI, E.A., MARGARIDO, V.P. \& GRAÇA, W.J. 2018. Update on the ichthyofauna of the Piquiri River basin, Paraná, Brazil: a conservation priority area. Biota Neotrop. 18(2): e20170350. http://dx.doi.org/10.1590/1676-0611-BN-2017-0350 (last access 23 August 2018).

CETRA, M., BARRELLA, W., LANGEANI NETO, F., MARTINS, A.G., MELLO, B.J. \& ALMEIDA, R.S. 2012. Fish fauna of headwater streams that cross Atlantic Forest of south São Paulo state. Check List 8(3): 421-425.

CETRA, M., MATTOX, G.M.T., FERREIRA, F.C., GUINATO, R.B., SILVA, F.V. \& PEDROSA, M. 2016. Headwater stream fish fauna from the Upper Paranapanema River basin. Biota Neotrop. 16(3): e20150145. http://dx.doi. org/10.1590/1676-0611-BN-2015-0145 (last access 23 August 2018).

CLARO-GARCÍA, A., ASSEGA, F.M. \& SHIBATTA, O.A. 2018. Diversity and distribution of ichthyofauna in streams of the middle and lower Tibagi river basin, Paraná, Brazil. Check List 14(1): 43-53.

DAGA, V.S., SKÓRA, F., PADIAL, A.A., ABILHOA, V., GUBIANI, É.A. \& VITULE, J.R.S. 2015. Homogenization dynamics of the fish assemblages in Neotropical reservoirs: comparing the roles of introduced species and their vectors. Hydrobiologia 746(1): 327-347.

DAGA, V.S., DEBONA, T., ABILHOA, V., GUBIANI, É.A. \& VITULE, J.R.S 2016. Non-native fish invasions of a Neotropical ecoregion with high endemism: a review of the Iguaçu River. Aquat. Invasions 11(2): 209-223.

DAJOZ, R. 1983. Ecologia geral. Vozes, Petrópolis.

DELARIVA, R.L. \& SILVA, J.C. 2013. Fish fauna of headwater streams of Perobas Biological Reserve, a conservation unit in the Atlantic Forest of the Northwestern Paraná State, Brazil. Check List 9(3): 549-554.

DELARIVA, R.L., NEVES, M.P., LARENTIS, C., KLIEMANN, B.C.K., BALDASSO, M.C. \& WOLFF, L.L. 2018. Fish fauna in forested and rural streams from an ecoregion of high endemism, lower Iguaçu River basin, Brazil. Biota Neotrop. 18(3): e20170459. http://dx.doi.org/10.1590/16760611-bn-2017-0459 (last access 23 August 2018).

ESCHMEYER, W.N. \& FONG, J.D. 2018. SPECIES BY FAMILY/ SUBFAMILY. http://researcharchive.calacademy.org/research/ichthyology/ catalog/SpeciesByFamily.asp (last access 22 August 2018).

FERREIRA, F.C., SOUZA, U.P. \& PETRERE JR, M. 2010. Zonação longitudinal da ictiofauna em ambientes lóticos. Boletim da Sociedade Brasileira de Limnologia 38: 1-9.

FERREIRA, F. S., DUARTE, G. S. V., SEVERO-NETO, F., FROEHLICH O. \& SÚAREZ, Y. R. 2017. Survey of fish species from plateau streams of the Miranda River Basin in the Upper Paraguay River Region, Brazil. Biota Neotrop. 17(3): e20170344. http://dx.doi.org/10.1590/1676-0611BN-2017-0344 (last access 23 August 2018).

FIGUEREDO, C.C. \& GIANI, A. 2005. Ecological interactions between Nile tilapia (Oreochromis niloticus, L.) and the phytoplanktonic community of the Furnas Reservoir (Brazil). Freshwater Biol. 50(8): 1391-1403.

FRANCO-MAGALHAES, A.O.B., HACKSPACHER, P.C., GLASMACHER, U.A. \& SAAD, A.R. 2010. Rift to post-rift evolution of a "passive" continental margin: the Ponta Grossa Arch, SE Brazil. Int. J. Earth Sci. 99(7): 1599-1613.

FROTA, A., DEPRÁ, G.C., PETENUCCI, L.M. \& GRAÇA, W.J. 2016a. Inventory of the fish fauna from Ivaí River basin, Paraná State, Brazil. Biota Neotrop. 16(3): e20150151 http://dx.doi.org/10.1590/1676-0611BN-2015-0151 (last access 23 August 2018).

FROTA, A., GONÇALVES, E.V.R., DEPRÁ, G.C. \& GRAÇA, W.J. 2016b. Inventory of the ichthyofauna from the Jordão and Areia river basins (Iguaçu drainage, Brazil) reveals greater sharing of species than thought. Check List 12(6): 1995.
FU, C., WU, J., WANG, X., LEI, G. \& CHEN, J. 2004. Patterns of diversity, altitudinal range and body size among freshwater fishes in the Yangtze River Basin, China. Glob. Ecol. Biogeogr. 13(6): 43-552.

GARAVELLO, J.C. \& SAMPAIO, F.A.A. 2010. Five new species of genus Astyanax Bird \& Girard, 1854 from Rio Iguaçu, Paraná, Brazil (Ostariophysi, Characiformes, Characidae). Braz. J. Biol. 70(3): 847-865.

GUBIANI, É.A., RUARO, R., RIBEIRO, V.R., EICHELBERGER, A.C.A., BOGONI, R.F., LIRA, A.D., CAVALLI, D., PIANA, P.A. \& GRAÇA, W.J. 2018. Non-native fish species in Neotropical freshwaters: how did they arrive, and where did they come from? Hydrobiologia 817(1): 57-69.

HOFFMANN, A.C., NASCIMENTO, R.H.C. \& SHIBATTA, O.A. 2015. Fish fauna from tributaries throughout the Tibagi River basin, upper Paraná basin, Brazil. Check List 11(6): 1815.

HORTAL, J., BELLO, F., DINIZ-FILHO, J.A.F., LEWINSOHN, T.M., LOBO, J.M. \& LADLE, R.J. 2015. Seven shortfalls that beset large-scale knowledge of biodiversity. Annu. Rev. Ecol. Evol. Syst. 46: 523-549.

INGENITO, L.F.S. \& BUCKUP, P.A. 2007. The Serra da Mantiqueira, southeastern Brazil, as a biogeographical barrier for fishes. J. Biogeogr. 34(7) 1173-1182.

INGENITO, L.F.S., DUBOC, L.F. \& ABILHOA, V. 2004. Contribuição ao conhecimento da ictiofauna da bacia do alto rio Iguaçu, Paraná, Brasil. Arquivos de Ciências Veterinárias e Zoológicas da UNIPAR 7(1): 23-36.

JARAMILLO-VILLA, U., MALDONADO-OCAMPO, J.A. \& ESCOBAR, F. 2010. Altitudinal variation in fish assemblage diversity in streams of the central Andes of Colombia. J. Fish Biol. 76(10): 2401-2417.

LARENTIS, C., DELARIVA, R.L., GOMES, L.C., BAUMGARTNER, D.,

RAMOS, I.P. \& SEREIA, D.A.O. 2016. Ichthyofauna of streams from the lower Iguaçu River basin, Paraná State, Brazil. Biota Neotrop. 16(3): e20150117 http://dx.doi.org/10.1590/1676-0611-BN-2015-0117 (last access 23 August 2018).

LIMA, L.B., OLIVEIRA, F.J.M., GIACOMINI, H.C. \& LIMA-JUNIOR, D.P 2018. Expansion of aquaculture parks and the increasing risk of non-native species invasions in Brazil. Rev. Aquacult. 10(1): 111-122.

LOBÓN-CERVIÁ, J. 1991. Dinámica de poblaciones de peces en rios: pesca eléctrica y métodos de capturas sucesivas en la estima de abundancias. Monografia, Consejo Superior de Investigaciones Científicas, Museo Nacional de Ciencias Naturales.

LOMOLINO, M.V. 2004. Conservation biogeography. In Frontiers of biogeography: new directions in the geography of nature (M.V. Lomolino \& L.R. Heaney, eds). Sinauer Associates, Sunderland, p.293-296.

LOWE-MCCONNELL, R.H. 1999. Estudos ecológicos de comunidades de peixes tropicais. EDUSP, São Paulo.

LUCINDA, P.H.F. 2008. Systematics and biogeography of the genus Phalloceros Eigenmann, 1907 (Cyprinodontiformes: Poeciliidae: Poeciliinae), with the description of twenty-one new species. Neotrop. Ichthyol. 6(2): 113-158.

MAZZONI, R., NOVAES, V.C. \& IGLESIAS-RIOS, R. 2011. Microhabitat use by Phalloceros harpagos Lucinda (Cyprinodontiformes: Poeciliidae) from a coastal stream Southeast Brazil. Neotrop. Ichthyol. 9(3): 665-672.

MELO, B.F., BENINE, R.C., BRITZKE, R., GAMA, C.S. \& OLIVEIRA, C. 2016. An inventory of coastal freshwater fishes from Amapá highlighting the occurrence of eight new records for Brazil. ZooKeys 606: 127-140.

MENEZES, N.A., WEITZMAN, S.H., OYAKAWA, O.T., LIMA, F.C.T., CASTRO, R.M.C. \& WEITZMAN, M.J. 2007. Freshwater fishes of Mata Atlântica: preliminary list of species and comments on conservation of Neotropical freshwater fishes. Museu de Zoologia - Universidade de São Paulo, São Paulo.

MEYER, C., KREFT, H., GURALNICK, R. \& JETZ, W. 2015. Global priorities for an effective information basis of biodiversity distributions. Nat. Commun. 6:82221.

MIRANDE, J.M. 2018. Morphology, molecules and the phylogeny of Characidae (Teleostei, Characiformes). Cladistics. http://dx.doi.org/10.1111/cla.12345 
MORAIS-SILVA, J.P., OLIVEIRA, A.V., FABRIN, T.M.C., DIAMANTE, N.A., PRIOLI, S.M.A.P., FROTA, A., GRAÇA, W.J. \& PRIOLI, A.J. 2018. Geomorphology influencing the diversification of fish in small-order rivers of neighboring basins. Zebrafish 15(4): 389-397.

OLIVEIRA, A.G., GOMES, L.C., LATINI, J.D. \& AGOSTINHO, A.A. 2014. Implications of using a variety of fishing strategies and sampling techniques across different biotopes to determine fish species composition and diversity. Nat. Conservação 12(2): 112-117.

ORSI, M.L. \& AGOSTINHO, A.A. 1999. Introdução de espécies de peixes por escapes acidentais de tanques de cultivo em rios da Bacia do rio Paraná, Brasil. Rev. Bras. Zool. 16(2): 557-560.

OTA, R.R., MESSAGE, H.J., GRAÇA, W.J. \& PAVANELLI, C.S. 2015. Neotropical Siluriformes as a model for insights on determining biodiversity of animal groups. PLoS ONE 10(7): e0132913.

OYAKAWA, O.T. \& MENEZES, N.A. 2011. Checklist dos peixes de água doce do Estado de São Paulo, Brasil. Biota Neotrop. 11(1a): 19-32 http://www. biotaneotropica.org.br/v11n1a/pt/abstract?inventory+bn0021101a2011 (last access 18 August 2018).

OYAKAWA, O.T., AKAMA, A., MAUTARI, K.C. \& NOLASCO, J.C. 2006. Peixes de riachos da Mata Atlântica. Neotrópica, São Paulo.

PADIAL, A.A., AGOSTINHO, A.A., AZEVEDO-SANTOS, V.M., FREHSE, F.A., LIMA-JUNIOR, D.P., MAGALHÃES, A.L.B., MORMUL, R.P., PELICICE, F.M., BEZERRA, L.A.V., ORSI, M.L., PETRERE-JUNIOR, M. \& VITULE, J.R.S. 2017. The "Tilapia Law" encouraging non-native fish threatens Amazonian River basins. Biodivers. Conserv. 26(1): 243-246.

PAGOTTO, J.P.A., VERÍSSIMO, S., GOULART, E. \& MISE, F.T. 2012. Fishes (Osteichthyes: Actinopterygii) from the Pirapó River drainage, upper Paraná River basin, Paraná state, Brazil. Check List 8(3):463-468.

REIS, R.E., ALBERT, J.S., DI DARIO, F., MINCARONE, M.M., PETRY, P. \& ROCHA, L.A. 2016. Fish biodiversity and conservation in South America. J. Fish Biol. 89(1): 12-47.
RIBEIRO, A.C. 2006. Tectonic history and the biogeography of the freshwater fishes from the coastal drainages of eastern Brazil: an example of faunal evolution associated with a divergent continental margin. Neotrop. Ichthyol. 4(2): 225-246.

ROXO, F.F., ALBERT, J.S. SILVA, G.S.C., ZAWADZKI, C.H., FORESTI, F. \& OLIVEIRA, C. 2014. Molecular Phylogeny and Biogeographic History of the Armored Neotropical Catfish Subfamilies Hypoptopomatinae, Neoplecostominae and Otothyrinae (Siluriformes: Loricariidae). PLoS ONE 9(8): e105564.

ROXO, F.F., LUJAN, N.K., TAGLIACOLLO, V.A., WALTZ, B.T., SILVA, G.S.C., OLIVEIRA, C. \& ALBERT, J.S. 2017. Shift from slow- to fast-water habitats accelerates lineage and phenotype evolution in a clade of Neotropical suckermouth catfishes (Loricariidae: Hypoptopomatinae). PLoS ONE 12(6): e0178240.

ROXO, F.F., ZAWADZKI, C.H., ALEXANDROU, M.A., COSTA SILVA, G.J., CHIACHIO, M.C., FORESTI, F. \& OLIVEIRA, C. 2012. Evolutionary and biogeographic history of the subfamily Neoplecostominae (Siluriformes: Loricariidae). Ecol. Evol. 2(10): 2438-2449.

SANCHES, F.H.C., MIYAI, C.A., COSTA, T.M., CHRISTOFOLETTI, R.A., VOLPATO, G.L. \& BARRETO, R.E. 2012. Aggressiveness overcomes body-size effects in fights staged between invasive and native fish species with overlapping niches. PLoS ONE 7(1): e29746.

SCHAEFER, S.A. 1998. Conflict and resolution: impact of new taxa on phylogenetic studies of the neotropical cascudinhos (Siluroidei: Loricariidae). In Phylogeny and classification of neotropical fishes (L.R. Malabarba, R.E. Reis, R.P. Vari, Z.M.S. Lucena \& C.A.S. Lucena, eds). EDIPUCRS, Porto Alegre, p.375-400.

SILVEIRA, L.F., BEISIEGEL, B.M., CURCIO, F.F., VALDUJO, P.H., DIXO, M., VERDADE, V.K., MATTOX, G.M.T. \& CUNNINGHAM, P.T.M. 2010. What use do fauna inventories serve? Estudos avançados 24(68): 173-207.

Received: 01/10/2018

Revised: $28 / 11 / 2018$

Accepted: $11 / 12 / 2018$

Published online: 21/01/2019 